\section{Inositol Phosphatide in Peas}

Some properties and analytical data concerning an inositol phosphatide of peas have been reported previously ${ }^{1,2}$. The availability of accurate methods for the determination of inositol in lipids, both by microbiological ${ }^{3}$ and chemical means 1,5 , has made it possible to conduct further experiments which are reported here.

The quantity of inositol phosphatide fraction obtained by Wagenknecht's modification of Carter's procedure $^{6}$ has been reported to inerease during storage of raw peas (Pisum sativum) at $-17 \cdot 8^{\circ} \mathrm{C}$. for periods of several days to several months ${ }^{2}$. Since this inositol phosphatide fraction is known to contain impurities it was thought desirable to determine whether the percentage of inositol in the fractions was constant with time over the entire period of frozen storage. Aliquots of the inositol phosphatide fractions obtained from peas of Pluperfect variety were subjected to hydrolysis with $4 N$ hydrochloric acid in sealed tubes at $120^{\circ} \mathrm{C}$. for $16 \mathrm{hr}$. A modification of the periodate oxidation methods of Agranoff et al. ${ }^{5}$ and Le Baron et al. ${ }^{4}$ was used to determine inositol content of the hydrolysates. The results (Table 1) indicate that the percentage of inositol in these samples varies with time at $-17 \cdot 8^{\circ} \mathrm{C}$., but the total weight of inositol in the fractions is relatively invariant over the period from two days to four months of storage.

Table 1. Inositol Content of Pea Inositol Phosphatide Fractions

\begin{tabular}{|c|c|c|c|}
\hline $\begin{array}{c}\text { Duration of } \\
\text { frozen storage }\end{array}$ & $\begin{array}{c}\text { Inositol* } \\
\text { (per cent) }\end{array}$ & $\begin{array}{c}\text { Inositol phosphatide } \\
\text { (mgm.) }\end{array}$ & $\begin{array}{c}\text { Inositol content } \\
\text { (mgm.) }\end{array}$ \\
\hline 0 days & $6 \cdot 4$ & 23 & $1 \cdot 5$ \\
2 days & $1 \cdot 8$ & 133 & $2 \cdot 5$ \\
2 months & 1.0 & 229 & $2 \cdot 3$ \\
4 months & $1 \cdot 0$ & 241 & $2 \cdot 4$ \\
6 months & $1 \cdot 1$ & 169 & $1 \cdot 8$ \\
\hline
\end{tabular}

* Determined by modified periodate oxidation procedure (refs. 2 4 and 5).

An enzymatic liberation of components of the inositol phosphatide fraction had previously been postulated, based on the observation that the inositol phosphatide content of raw (but not of heat-treated) peas increased with time ${ }^{2}$. On the basis of the results presented here it would appear that this increase is caused by the enzymatic liberation, during frozen storage, of inositol-free lipid materials the solubility properties of which are sufficiently similar to those of phosphatidyl inositol to allow them to be extracted with the inositol phosphatide fraction.

Although several components were known to be present in the inositol phosphatide fraction, as was shown by chromatographic methods ${ }^{2}$, previous paper chromatographic results gave no evidence for the presence of free inositol. As a further check on the absence of free inositol a sample of the water-soluble intact potassium form, which had been prepared from the calcium-magnesium mixed salt as described in a previous publication ${ }^{1}$, was analysed for inositol by the excellent microbiological assay of $\mathrm{McKibbin}^{3}$, utilizing Saccharomyces carlsbergensis strain 4228 . The purified potassium salt of the inositol phosphatide fraction was shown to contain less than $1 \mu \mathrm{gm}$. of free inositol per milligram.

Paper chromatographic evidence from another laboratory (Benson, A. A., personal communication) indicated that the calcium-magnesium mixed salts of pea inositol phosphatide contained, besides monophosphoinositide, components possessing the
$R_{F}$ values of glycerophosphorylglycerol, phosphatidyl ethanolamine, phosphatidic acid, and some free inositol. The results presented here confirm that the purified potassium salt of the inositol phosphatide fraction contains inositol only in the bound form.

L. M. LEWIN*

A. C. WAGENKNECHT $\dagger$

New York State Agricultural Experiment Station, Cornell University, Geneva, New York.

* Present address: Division of Biochemistry, Department of Biology, Massachusetts Institute of Technology. $\dagger$ Present address: Fundam
Mills, Inc., Minneapolis, Minn.

${ }^{1}$ Wagenknecht, A. C., Lewin, I. M., and Carter, H. E., J. Biol. Chem." Wagenknecht, A. C., I
234, 2265 (1959).

${ }^{2}$ Lewin, L. M., and Wagenknecht, A. C., Arch. Biochem. and Biophys. 87, 239 (1960).

"McKibbin, J. M., in "Methods of Biochemical Analysis", 7, 111 (Interscience, New York, 1959).

'Le Baron, F. N., Folch, J., and Rothleder, E. E., Fed. Proc., 16, 209 (1957).

s Agranoff, B. W., Bradley, R. M., and Brady, R. O., J. Biol. Chem., 233, 1077 (1958)

'Wagenknecht, A. C., J. Amer. Oil Chemists' Soc., 34, 509 (1957).

\section{5-Deoxycytidylic Acid-deaminating Activity in Human Gastric Mucosa and Other Adult Mammalian Tissues}

The enzymatic deamination of deoxycytidylic acid to deoxyuridylic acid in sea urchin eggs and embryos has been demonstrated by Scarano ${ }^{1}$ and Scarano and Maggio ${ }^{2}$. Moreover, later results obtained by Scarano and Tallarico ${ }^{3}$ on the presence of deoxycytidylic acid-deaminase in livers of rat, chicken, rabbit in various stages of their embryonic development may indicate that this enzymatic activity, in developing or regenerating tissues, is proportional to their growth-rate. This latter view was confirmed in experiments by Maley and Maley ${ }^{4}$ on the determination of this enzymatic activity in embryonic tissues, in some spontaneous and experimental tumours and in regenerating livers.

In order to ascertain whether deoxycytidylic aciddeaminase is only characteristic of tissues in evolution or is common to tissues in continuous physiological regeneration, we examined several adult mammalian tissues for this enzyme activity. The tissues and organs investigated have been chosen in view of their active cellular proliferation.

The experimental procedure was essentially that proposed by Scarano ${ }^{1}$. The homogenates were prepared by scrapping of the mucosa surface. The specific activity is referred to as $\mu$ moles of deoxycytidylic acid deaminated in $10 \mathrm{~min}$. per $10 \mathrm{mgm}$. nitrogen of the homogenate (the deamination of $1 \mu$ mole of deoxycytidylic acid giving a $\Delta A_{280}$ of $-0 \cdot 344$ ). The human tissues used for the enzymatic assays were collected immediately from surgical operations. Histological examinations were carried out on each of the specimens used.

The results obtained for the human gastro-enteric mucosa and for other mammalian tissues are reported in Table 1.

The results indicate that the rabbit gastric mucosa has a deoxycytidylic acid-deaminating activity although in a lesser amount as compared to the human. This enzymatic activity is not found in other segments of rabbit gastro-enteric mucosa and in testicle, being scarcely detectable in bone marrow. Cat and ox gastric mucosa have also been examined, and a very low deoxycytidylic acid-deaminating activity was found. 